\title{
Performance measurement framework for product-service systems development: a balanced scorecard approach
}

\author{
Koteshwar Chirumalla* \\ and Alessandro Bertoni \\ Division of Innovation and Design, \\ Luleå University of Technology, \\ 97187 Luleå, Sweden \\ E-mail: koteshwar.chirumalla@ltu.se \\ E-mail: alessandro.bertoni@ltu.se \\ ${ }^{*}$ Corresponding author
}

\section{Aditya Parida}

Division of Operation, Maintenance Engineering, Luleå University of Technology,

97187 Luleå University of Technology, Sweden

E-mail: aditya.parida@ltu.se

\section{Christian Johansson}

Division of Innovation and Design,

Luleå University of Technology,

97187 Luleå, Sweden

E-mail: Christian.johansson@1tu.se

\section{Marco Bertoni}

Department of Mechanical Engineering, Blekinge Institute of Technology,

37179 Karlskrona, Sweden

E-mail: marco.bertoni@bth.se

\begin{abstract}
The paper proposes a framework for analysing the performances of product-service systems (PSSs) development processes using a balanced scorecard (BSC) as an instrument to guide the implementation and the evaluation of new methods and tools. Emerging from a case study in the aerospace industry, the paper discusses the main challenges in PSS development and proposes a performance measurement framework for PSS development based on multi-criteria indicators. Finally, the benefits of a framework for PSS development performance measurement are discussed.
\end{abstract}

Keywords: PSS; product-service system; performance measurement; balanced scorecard; performance indicators; product development; cross-functional teams; aerospace. 
Reference to this paper should be made as follows: Chirumalla, K., Bertoni, A., Parida, A., Johansson, C. and Bertoni, M. (2013) 'Performance measurement framework for product-service systems development: a balanced scorecard approach', Int. J. Technology Intelligence and Planning, Vol. 9, No. 2, pp.146-164.

Biographical notes: Koteshwar Chirumalla is a $\mathrm{PhD}$ student in Product Innovation at the Division of Innovation and Design at Luleå University of Technology in Sweden. His research interests include product-service systems development, knowledge lifecycle management, web 2.0 technologies and experience sharing. The main purpose of his research is to develop methods and tools for the experience capturing and sharing to support early stages of product innovation projects.

Alessandro Bertoni is a $\mathrm{PhD}$ student in Product Innovation at the Division of Innovation and Design at Luleå University of Technology in Sweden. With a background on Management Engineering, he is focusing his research on studying new methods and tools for the assessment and communication of the value of products and services in the early stages of the design process. He has mainly performed his work in close collaboration with the aerospace industry.

Aditya Parida is an Associate Professor in the Division of Operation and Maintenance Engineering at Luleå University of Technology, Sweden. $\mathrm{He}$ obtained his $\mathrm{PhD}$ in Operation and Maintenance Engineering. His areas of research are asset management, maintenance performance measurement and model, RCM and e-maintenance. Besides teaching, he is actively involved in research and projects. $\mathrm{He}$ is the author of 73 peer-reviewed journal and conference papers, besides two books, three book chapters and guest editors of four special issues of international journals.

Christian Johansson is a Postdoctoral Researcher with experience and skills from applied research projects in primarily engineering product development. His main research interest is in knowledge-based support to drive product development. His doctoral work analysed the decision-making phase and role of information and knowledge in Stage-Gate process. As an outcome, the concept of knowledge maturity was presented as a way of assessing the base for decision-making. By applying the maturity scale appropriately, sometimes mitigating, actions can be taken where it is needed the most from a knowledge perspective.

Marco Bertoni is an Associate Professor at Blekinge Institute of Technology, working with a focus on the conceptual design stage of product service systems, in close academia/industry collaboration. With an international research background from EU FP6 and FP7 aerospace projects, his research work focuses on value-driven design methods to complement traditional requirements management processes. In this area, he investigated the engineering need for visualising technical performances and in-service value of complex system, and developing decision-making models to guide early concept selection activities. In parallel, he has worked in the domain of engineering knowledge management, exploring mechanisms for experience capturing and sharing, to enable such decision-making models to be constructed and populated. 


\section{Introduction}

In today's dynamic global business environment, many manufacturing companies are searching for new and innovative ways to achieve and retain competitive advantage. Companies have begun to realise that this objective is not achievable purely through continuous technical improvements of their physical products; rather, it requires a deeper understanding of the needs, expectations and perceived value scales of their customers (Woodruff, 1997). Companies are, therefore, exploring the possibility of moving beyond the 'traditional' product offerings to become more service-oriented companies, offering solutions that include 'sale of use' rather than merely 'sale of product' (Baines et al., 2007), thus providing product-service system (PSS). An example of PSS offering is the 'TotalCare ${ }^{\circledR}$ ' package offered to airlines by the aircraft engine manufacturer Rolls-Royce (Harrison, 2006), which is delivering 'power-by-the-hour' rather than transferring ownership of the gas turbine engine. In this case, as a PSS provider, the aircraft engine manufacturer retains ownership and responsibility for Maintenance, Repair and Operations (MRO) throughout the all engine lifecycle, while the customer only pays for the number of hours flown by the engine.

This transition implies a major shift in the business operations, strategic thinking and management approaches (Oliva and Kallenberg, 2003; Brax, 2005; Johnstone et al., 2008), impacting not only the way products are offered, but also the way in which they are designed and developed (Isaksson et al., 2009; Wagner et al., 2012).

This paper takes into consideration the transition towards PSS offering happening today in the aerospace industry (Harrison, 2006), and grounds the analysis on two main emerging strategies towards service integration in product content:

- change in the way aeronautical components are designed, integrating a more value-driven perspective in product development (Collopy and Hollingswort, 2009; Bertoni et al., 2011)

- adoption of methods and tools to enhance system and subsystems knowledge acquisition, sharing and use (Chirumalla et al., 2012; Larsson et al., 2008).

Literature on PSS development largely discusses new methods and tools to be used during the product development stages (e.g., Tomiyama and Meijer, 2003; Van Halen et al., 2005; Morelli, 2006). However little research has been conducted on how to handle this strategic shift, and on how to measure the performances of a PSS development process.

Starting from the literature analysis of different performance measurement frameworks for PSS, the authors have investigated a balanced scorecard (BSC) approach to build a performance measurement framework suitable for PSS design, adopting an aerospace product development standpoint. Generally, one of the main advantages recognised to the BSC is that it adds strategic non-financial performance measures (intangibles) to traditional financial metrics (tangible) to give managers a more 'balanced' view of organisational performance (Kaplan and Norton, 1996).

The objective of this study is, therefore, to propose a multi-criteria hierarchical performance measurement framework, based on the BSC approach, to be used both as guidance and as a continuous feedback tool by managers in PSS design. The framework is intended to drive corrective actions and have a more objective overview on the behaviour of the PSS development process. 
The paper is structured as follows: Section 2 introduces performance measurement and BSC theory, and reviews previous work related to performance measurement in PSS development. Section 3 details the methodology. In Section 4, the performance measurement framework for PSS development is described in detail with respect to internal and external stakeholders, hierarchical levels, multi-criteria and performance indicators. Section 5 presents discussions of findings including pros and cons of using BSC in a PSS context.

\section{Performance measurement and product-service systems}

\subsection{Performance measurement}

Performance management has been recognised as an important area in several disciplines for measuring effectiveness of activities (e.g., Lebas, 1995). Neely (1998) defined performance measurement as the process of quantifying the efficiency and effectiveness of actions. These performances can be related to an individual employee, a group, a department, an organisation, or even to the organisational processes. Most of the companies are extensively using performance measurement to assess progress of their initiatives against quantifiable goals and objectives in terms of time, cost and quality (Neely, 1998; Bourne et al., 2005; Kennerly and Neely, 2003). Figure 1 shows how performance measurement can play a primary role in dividing the corporate vision and objectives into each departmental-level objective and strategy, thereby enabling the monitoring of key relevant areas (KRAs) and key performance indicators (KPIs) at each department level, while connecting to overall corporate strategies (Parida et al., 2003). In this way, performance measurement serves the purposes of identifying the areas that need attention, improving communications and accountability across departmental boundaries (Waggoner et al., 1999). Moreover, performance measurement usually provides feedback on activities with respect to meeting stakeholders' or customers' expectations and strategic objectives, thereby highlighting the need for improvement in areas with unsatisfactory performance (Bhagwat and Sharma, 2007).

As observed by Kaplan and Norton (1996), the first performance measurement frameworks were traditionally accounting based, focusing mainly on financial indicators. Over the years, researchers have proposed a number of frameworks, models and tools for designing performance measurement based on non-financial indicators such as quality, customer satisfaction and innovation (Ittner and Larcker, 1998; Nudurupati et al., 2011). Some of the most important frameworks and models, which have made significant impact on performance measurement and management, in practice, are BSC (Kaplan and Norton, 1996), Performance Prism (Neely and Adams, 2001), The Performance Measurement Matrix (Keegan et al., 1989) and Performance Pyramid (Lynch and Cross, 1991). Each of these frameworks provides a unique and different lens through which an organisation's performance can be viewed. Most of these frameworks tend to be one dimensional in perspective. As such, they only provide commitment to short-term improvement initiatives rather than to design a formalised performance measurement system (Kaplan and Norton, 1996, 2001). The BSC, however, integrates multiple perspectives, as a way to align an organisation's performance measures with its strategic plan and goals, thus improving managerial decision-making regularly in a continuous manner. 
Figure 1 Performance measurement from corporate level to different departmental level (see online version for colours)

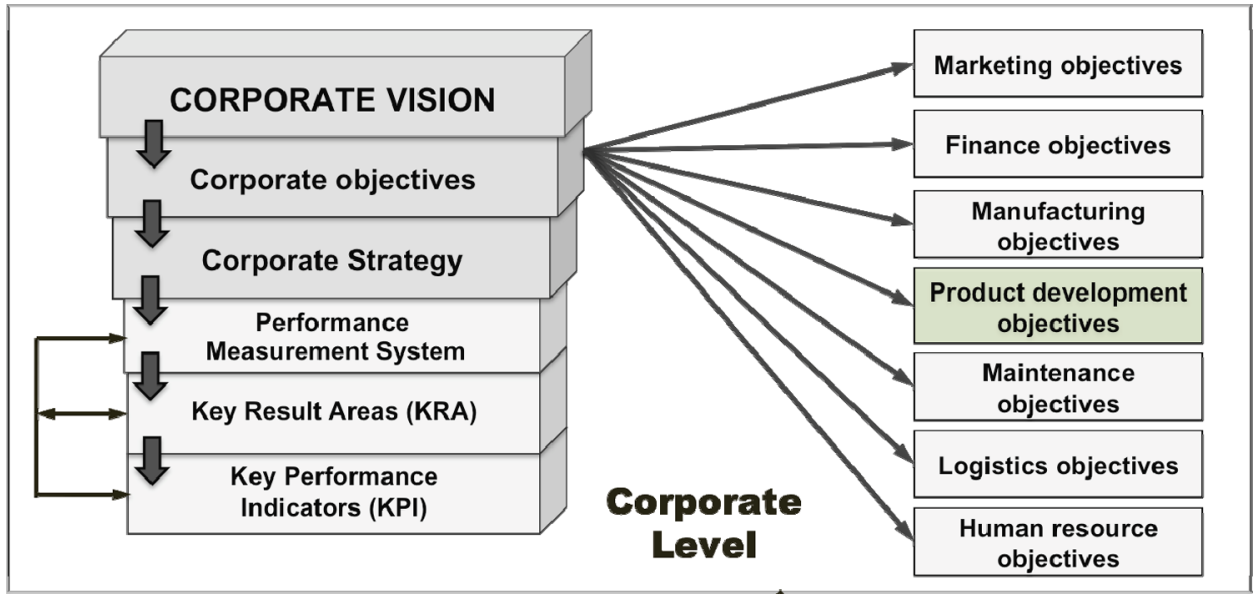

\section{Functional \& Project level}
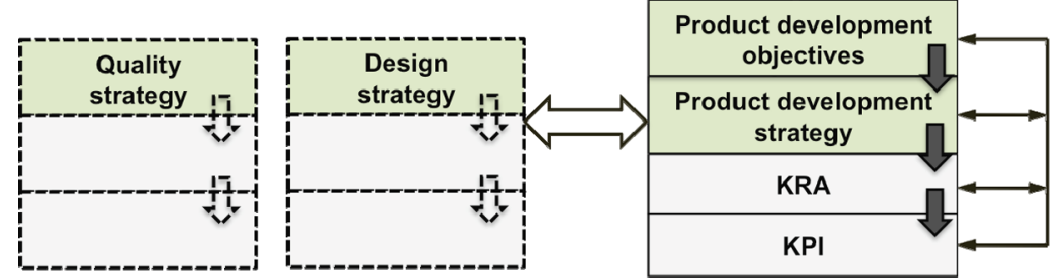

Source: Adapted from Parida et al. (2003)

\section{$2.2 \quad$ Balanced scorecard (BSC)}

Many businesses have adopted BSCs as a management tool to map their vision and strategy. The BSC concept provides a clear prescription to what companies should measure to 'balance' the financial perspective in implementation and control of their strategic plans, i.e., both short-term and long-term horizons (Kaplan and Norton, 1996). On the one hand, the BSC has the ability to transfer company goals to the operational levels of the organisation (Kaplan and Norton, 1996, 2001). On the other hand, it encourages the managers to approach the corporate vision and strategy from multiple perspectives (or criteria and KRAs) (Kaplan and Norton, 1996, 2001). At a general or conceptual level, the typical BSC includes at least the following four perspectives (Kaplan and Norton, 1996) as shown in Figure 2:

- Financial perspective: The strategy for the growth, profitability and risk viewed from the shareholder. For example, if we succeed, how will we look to our shareholders?

- Customer perspective: The strategy for creating value and differentiation from the perspective of the customer. For example, to achieve my vision, how must I look to my customers? 
- Internal business process perspective: The strategic priorities for various business processes that create customer and shareholder satisfaction. For example, to satisfy my customers, in which processes must I excel?

- Learning and growth perspective: The priorities are to create a climate that supports organisational change, innovation and growth. For example, to achieve my vision, how has my organisation to learn and improve?

These multiple perspectives are important in performance measurement because intangible assets, such as customer relationships, employee skills, knowledge and innovation, have become the major sources of competitive advantage in the information age compared with the industrial age, where the economy was based on tangible assets like the inventory, the land and the factory (Kaplan and Norton, 1996, 2001).

Figure 2 Balanced scorecard

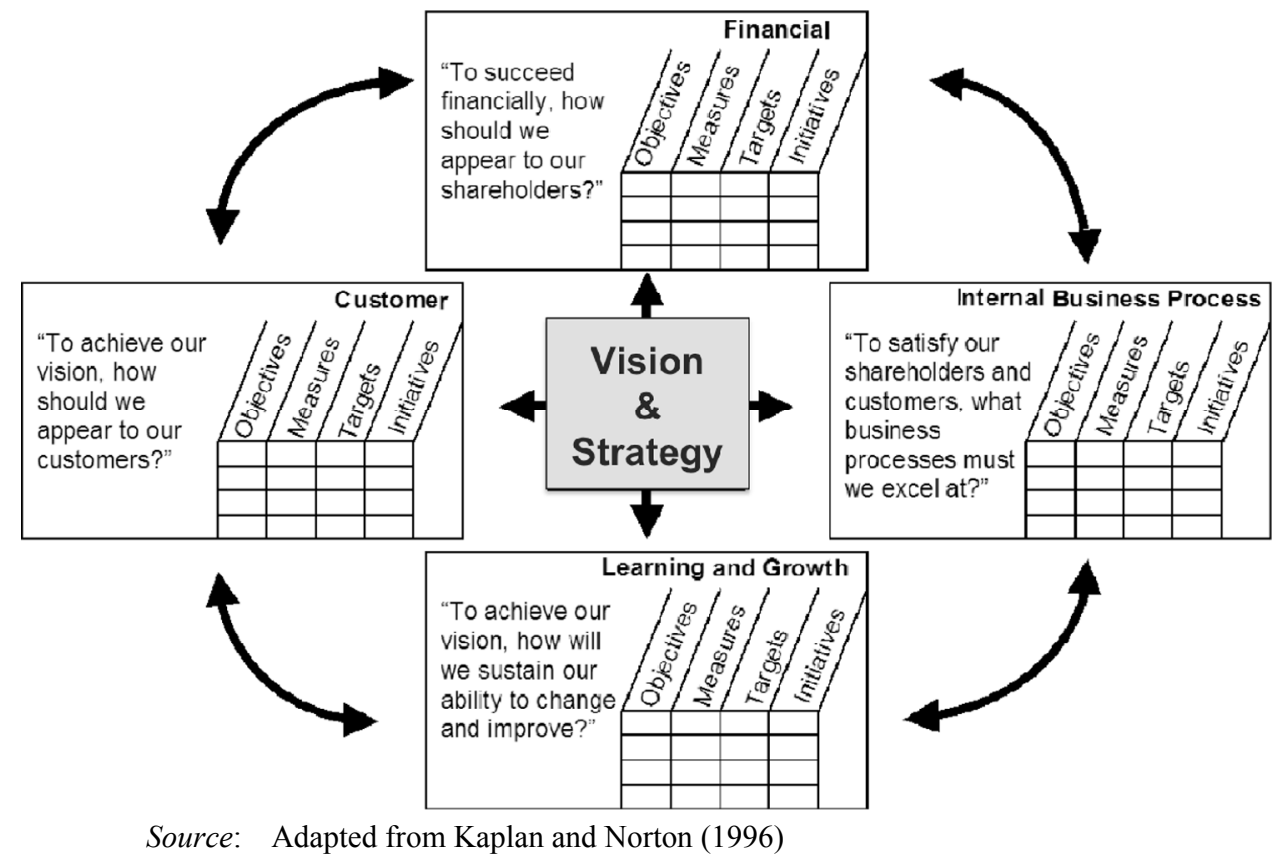

It is observed that companies using an integrated balanced performance measurement system perform better than those that do not measure their performance (Kennerly and Neely, 2003; Lingle and Schiemann, 1996). The BSC approach in business has the advantage of providing a mechanism for identifying the improvement areas and their associated performance measures for continuous improvement. Subsequently, various researchers (e.g., Abran and Buglione, 2003; Figge et al., 2002; Gaiardelli et al., 2007; Sveiby, 1997) have adopted BSC approach for measuring performances within their field of interest with adding additional new perspectives to the four perspectives identified by Kaplan and Norton (1996). The main reason is that since the BSC is directly linked to vision and strategy, the relevant perspectives and measures will vary across organisations depending on their specific goals and circumstances. For example, Figge et al. (2002) added a non-market perspective for linking sustainability management to business 
strategy and Abran and Buglione (2003) added a people perspective to tailoring the BSC for the information and communication technology (ICT) field. Similarly, Parida (2006) developed a performance measurement framework for the mining maintenance field with the addition of new criteria (or KRAs): equipment-related, maintenance task-related, health, safety and environment and employee satisfaction-related. Therefore, performance measurement and their selection of criteria will vary based on the field of interest and the conditions under which certain field works.

\subsection{Performance measurement for product-service systems development}

Product development is typically considered very demanding context, as it requires a mixture of overlapping activities to be effective (e.g., constrained costs, compressed time to market, improved quality and increased flexibility) (Driva et al., 2000). This poses challenges for companies to manage and measure the product development process effectively (Pawar and Driva, 1999; Nixon, 1999). Such situation is exacerbated in PSS development, which typically implies cross-functional, cross-disciplinary, cross-cultural and cross-organisational environments.

Accordingly, the designers in PSS context need to take into account the numerous factors to effectively understand the impact of changing design variables at the micro-level on the overall system 'value'. This stresses the criticality of good decisionmaking strategies during early conceptual design stages of PSS (Bertoni et al., 2011). Consequently, product development engineers need to know the goals of the company, cause-and-effect relationships behind costs and revenues, and they need to receive proper feedback concerning their decisions in the early phases (Sandström and Toivanen, 2002). However, the goals of the company and the future perspectives are, traditionally, explained to product engineers through the project budgeting and schedule (Pawar and Driva, 1999; Nixon, 1999).

A number of different approaches have been proposed and adopted to drive the development process towards the selection of more valuable solutions; however, an explicit linking between the objective of these approaches and the overall company objectives may be lacking, or may not be explicitly perceived by the managers across all the hierarchical levels. Furthermore, linking objectives to daily activities of PSS design process is crucial, as the linkage will ensure that development teams are working towards the objectives on daily basis, or teams have a clear direction to link their individual efforts to achieve the whole mission and objectives.

Sandström and Toivanen (2002) conclude that BSC is a good tool to communicate the strategic focus of the company to the design engineers, and to convey how decisions affect the design work. In addition to the above, the study reveals that BSC offers good opportunities to construct a proper feedback about their work to design engineers as it translates the company scorecard into specific goals and measures at individual level (Sandström and Toivanen, 2002).

In PSS perspective, Lange (2009) study demonstrates that existing performance measurement systems are not able to meet the identified requirements for measuring the performance of integrative industrial services into development process. Therefore, Lange (2009) study develops a service performance measurement system (SPMS) framework, as a structured set of operational performance indicators associated with service reference processes applicable for different service scenarios as the basis for the management of PSS (Lange, 2009). 
The recent study by Yang (2009) also reveals that the BSC approach is appropriate for a PSS context. He develops a three-level metrics structure for PSS, as shown in Figure 3, namely: Balanced Perspectives (financial, customer, business process and innovation and learning), PSS Components (product, service, team and network) and Capability areas (quality, cost, time, flexibility and sustainability).

Figure 3 The balanced framework of performance measurement for a PSS

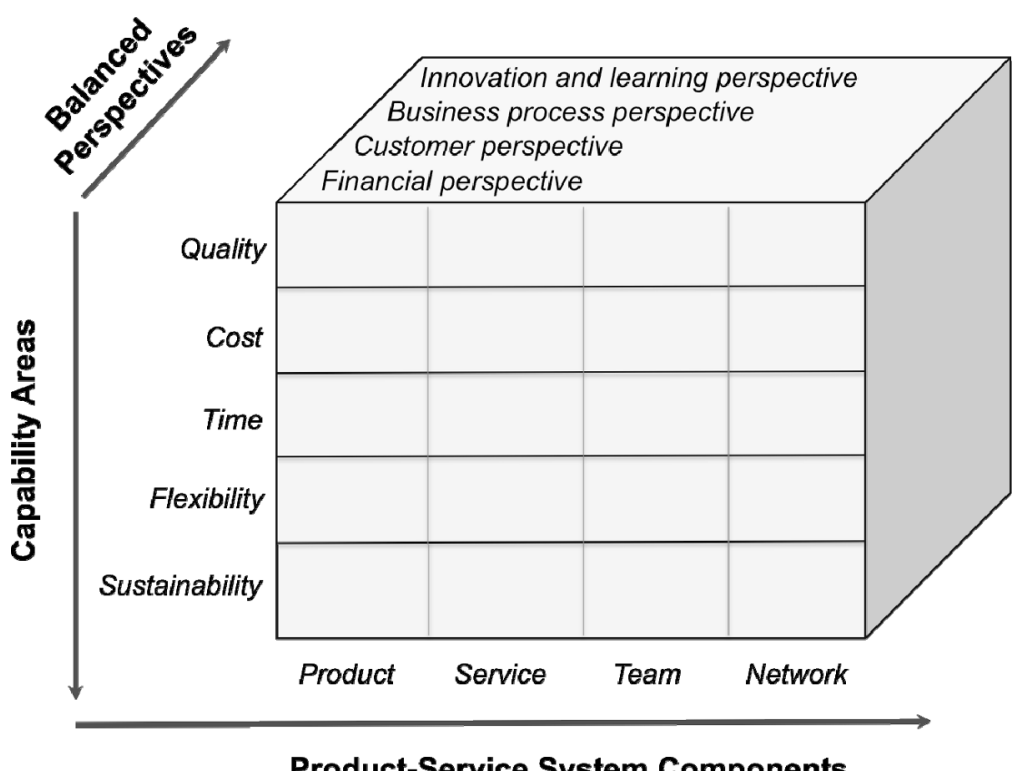

Source: Adopted from Yang (2009)

Yang (2009, p.549) further stressed the significance of a BSC approach in the PSS context, and noted that,
"the balanced performance evaluation of PSS not only helps organisations in faster and wider progress monitoring of their product and service operations, but can also help them in improving their internal and external functions of business such as engineering and design applications, production, quality improvement, materials management, service networks, quick response, gaining market shares, proper implementation of business strategies etc."

However, right now, there is no comprehensive research in the PSS field related to performance measurement topic. Although the existing research derived diverse performance indicators related to PSS, the issues related to selection of criteria, stakeholders and hierarchical levels as well as guidelines for continuous monitoring of performances have been overlooked in the literature. In addition, the researchers do generally not discuss the achievement of internal and external stakeholder's effectiveness in a PSS development. To overcome this gap, this paper proposes a multi-criteria hierarchical performance system for PSS development and suggests how companies can manage their PSS processes in a continuous manner. 


\section{Research method}

This study is based on the experiences from Swedish and EU-based research projects conducted in the aerospace industry. The study adopts a qualitative research methodology (Miles and Huberman, 1994), characterised by a case-study approach in one case (Yin, 2009) and by an action research approach (Avison et al., 1999) in the second one. The empirical data in these projects were collected through semi-structured interviews, formal/informal discussions, workshops, focus groups (Yin, 2009) and periodical meetings organised with different project partners. This has given access to a rich industrial context dealing with PSS development issues and challenges.

On the basis of the literature review and the interaction with several project partners, authors have developed performance measurement framework for PSS design using aerospace industry as an application example.

The developed framework has been discussed and improved, by means of focus groups, involving engineers and experts of different industrial fields, such as railway, hydropower and mining industry. The feedback from the meetings, together with the analysis of case studies of different applications of the BSC, have contributed to the final definition of the framework.

\section{Framework for performance measurement for PSS development using balanced scorecard}

This section presents an application of the BSC for the implementation and measurement of PSS design. After introducing internal and external stakeholders and their effectiveness, the first part describes the proposed hierarchical levels for measuring performances in PSS design, and the second part of the section proposes seven measurement criteria and summarises the multi-criteria hierarchical PSS performance measurement framework.

\subsection{Selection of internal and external stakeholders}

PSS providers are required to integrate and control all the needs that come from the downstream process during the early phases of design, such as manufacturing, operation, maintenance, repair, and remanufacturing (Isaksson et al., 2009). This situation calls for the necessity of considering a wider set of external stakeholders compared with traditional product development activities. Hence, the successful PSS design depends on how well the PSS-manufacturer combines and monitors the activities of multiple actors in the network (Windahl and Lakemond, 2006). Several authors highlighted this need in the literature, for example, Wisner et al. (2005) stresses that companies must first segment customers based on their service needs (i.e., the desired service level, the quantity and delivery frequency needed, and buying habits and trends), and then design a network to meet the needs of those customers. Morelli (2006) further confirmed that PSS providers need to identify their actors early in the development process, to consider their common interest and common goals, to design the whole system as well as to organise the interactions between them in an effective manner. 
This study exemplifies the proposed framework by using the example of an aerospace sub-system manufacturer adopting the vision of being the best partner for component supply aiming to become leading in innovative customised partnership solutions.

The external stakeholders assumed as relevant in such a case are sub-system suppliers, module suppliers, system integrator, service centres at airports, re-manufacturing centres, airliners, governmental environmental bodies, competitors and legal authorities (e.g., Chirumalla et al., 2012).

From an internal perspective, PSS design requires cross-functional and crossdisciplinary teams. For instance, the development of an aircraft engine requires the integration of knowledge from a broad range of disciplines, including mechanical design, electrical engineering, computer science, aerodynamics, material science, manufacturing, operations and maintenance, and service engineering (Prencipe, 2004). Although the number of internal stakeholders involved may vary from project to project, it is essential to involve a good 'balance' of competencies in the design activity.

\subsection{Selection of front-end and back-end needs}

The BSC tool can integrate both external and internal stakeholder perspectives with its nature of link-and-effect structure to achieve the total PSS development effectiveness (see Figure 4). BSC allows deriving front-end processes from the needs of the external stakeholders and matching with the back-end process from the internal capacity and capability of the internal stakeholders. The front-end and back-end needs have to be selected and analysed before deciding the number of criteria for PSS development performance measurement. On the basis of the literature review and the interaction with several project partners, several front-end needs are identified, including reduction of time-to-delivery, increase supply chain integration, increase product lifecycle time, increase passenger safety, reduction of operational cost and reduction of rework. Similarly, the back-end needs are derived from the requirements of the internal stakeholders' capabilities for the cross-functional integration, value-/service-driven design, product innovation capability, knowledge-sharing culture and learning organisation. This allows PSS providers to audit their internal capabilities and their partners in the networks in a continuous manner to determine whether they are consistent with the needs of the end customers. In this way, BSC can help the companies to reassess their internal and external capabilities in a continuous manner with respect to endcustomer needs.

The effectiveness of any performance measurement system lays in the way the company vision, overall objectives, strategies and performance indicators link and integrates each other. The linkage between visions, objectives and strategies and measures of performance are considered in our proposed framework. A logical causeand-effect structure has been created in the framework, while identifying and deciding the different performance indicators for each criterion to measure the PSS performance. The framework is designed to balance different criteria with respect to defined hierarchical levels, and integrated as a link-and-effect structure to achieve the total PSS development effectiveness from both external and internal stakeholder effectiveness, which would contribute to the overall objective of the organisation and its business units (see Figure 4). Accordingly, the total PSS development effectiveness = Internal effectiveness $\times$ External effectiveness. 
Figure 4 The structure of balanced and integrated PSS performance measurement framework linking to multi-criteria and multi-hierarchical levels

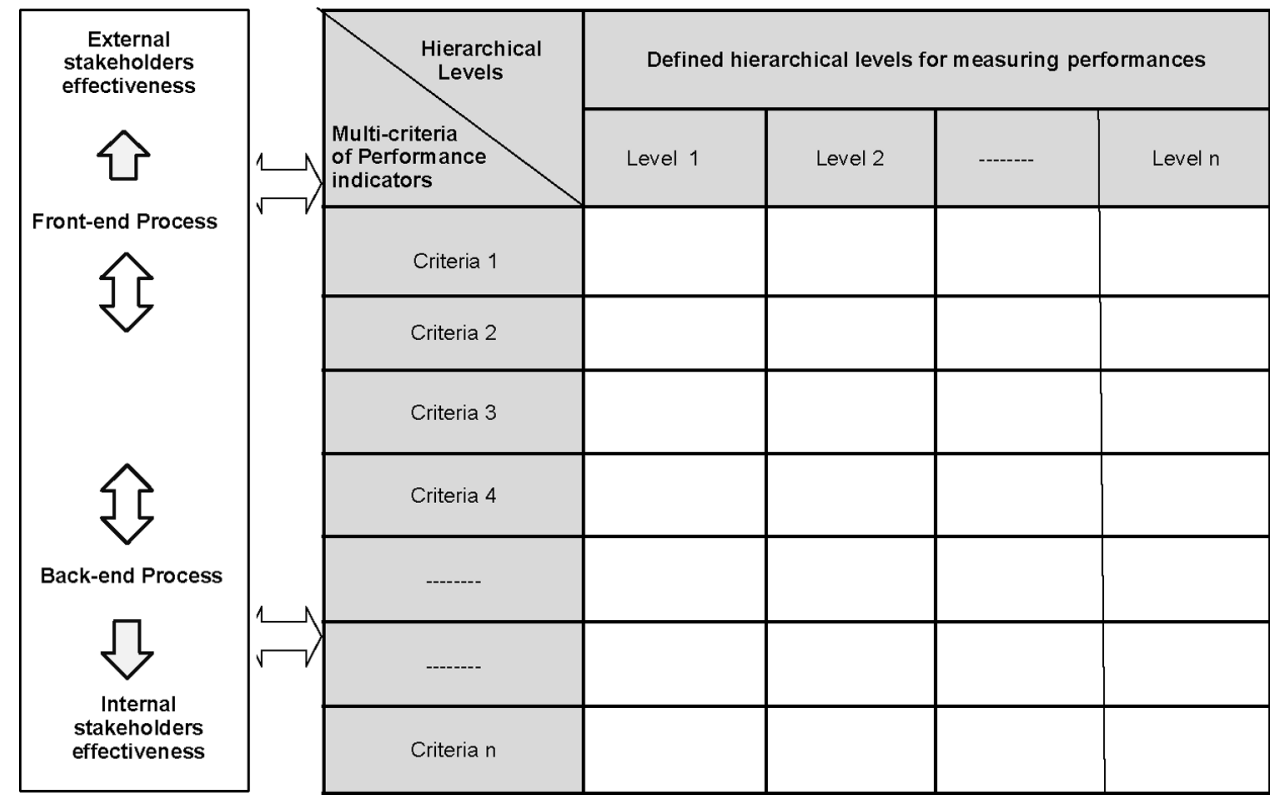

\subsection{Selection of hierarchical levels}

To measure the PSS development performances, three levels of hierarchical management categories are considered in the study namely strategic, tactical and operational, as shown in Figure 5.

In the performance measurement hierarchy, the strategic level (1) represents corporate top management, whereas the tactical level (2) represents business function management, and finally the operational level (3) represents both functional and project managements together. An additional level might be added, link to the management of small local teams, however since these groups are typically smaller in size, they are not considered in this study. For instance, considering product development as business function level, there are several functional levels present, such as computer aided design (CAD), finite element methods (FEMs), simulations, quality functions (on functional level), with current running projects, such as intermediate compressor project (on project level), which includes stress analysis teams, product support teams, solid mechanics teams, etc. (on team level).

Design projects are increasingly cross-functional, requiring the collaboration of stakeholders and expertise located all around the enterprise and that are often working on different projects concurrently. This can create synergies, or can increase the complexity, decreasing effectiveness and efficiency. However, these effects are cumbersome to measure if merely looking at a functional-level perspective. Thus, there is the necessity to frame a system able to collect the information about the performances of cross-functional projects, to be coupled with more functional-oriented measurement. To overcome this problem, the proposed framework selected level 3 at operational level, which is combination of both functional management and project management (see Figure 5). In this way, level 3 can fertilise cross-project learning, as companies often considered 
this as a main obstacle, and hence several learning opportunities from projects to functions are often missed that could lead organisations to pay a high price for repeating similar mistakes and missed opportunities (Fisher et al., 1998).

Figure 5 Defined hierarchical levels for the performance measurement framework for PSS design in the aerospace industry

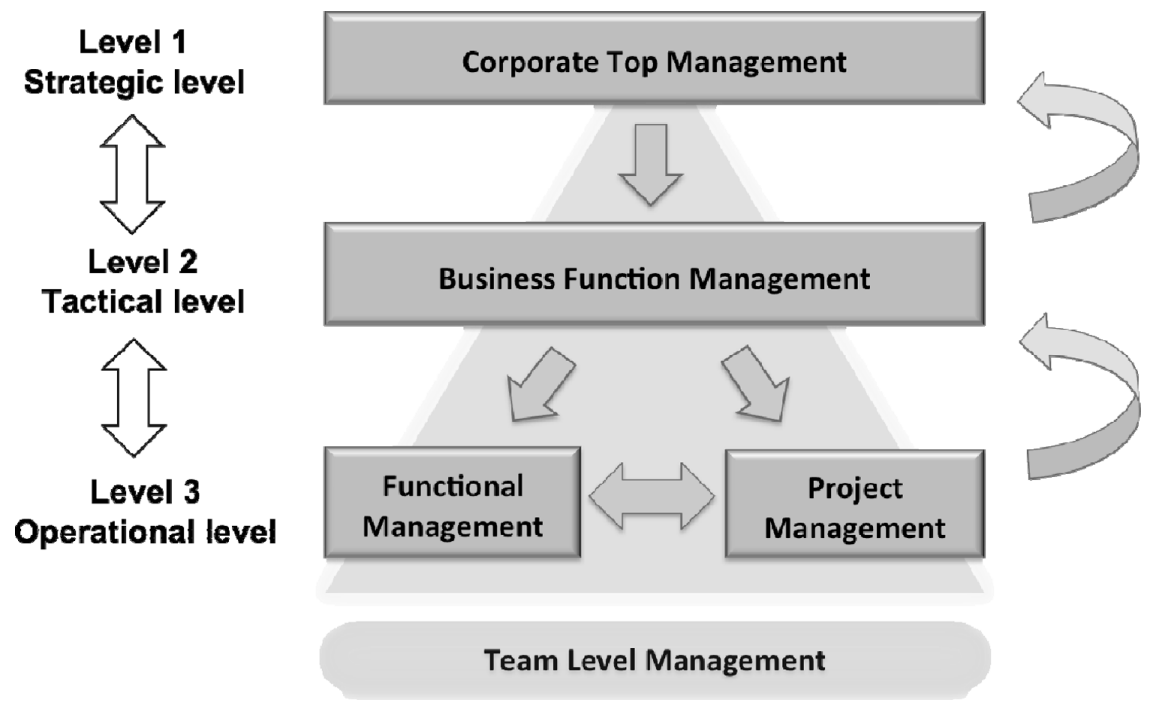

\subsection{Selection of performance criteria and its indicators}

The development and identification of performance indicators for an organisation is undertaken from the vision, objectives and strategy points of view and on the basis of the needs and requirements of both the external and the internal stakeholders.

In every design process, designers and engineers are asked to choose among a set of design alternatives aiming to select the one that best fits with the original intent. Normally, such information is cascaded down to a set of criteria, which translate the high-level objectives into tangible parameters. The selection of factors or variables constituting various performance criteria, such as productivity, effectiveness and efficiency, is an important step in developing a performance measurement system in an organisation. In a PSS performance measurement system, there are a number of criteria or goal functions, which needs to be considered from different stakeholders' view. These criteria can be broken down to different PSS development indicators. These PSS development indicators need to be integrated from operational level to the strategic level.

In this development process of the performance measurement framework, the basic four perspectives of Kaplan and Norton's (1996) BSC are considered. In addition, the perspectives related to service, safety and sustainability, and innovative capability, culture and environment are considered to make this performance measurement system balanced and holistic from the organisational point of view. Therefore, the proposed performance measurement for PSS development is considered and included the following seven criteria and some indicators for each criterion are listed in Table 1: 
- Customer focus-related: Moving towards PSS prompt companies to rearrange their businesses from a transaction-based to long-term-relationship-based approach to satisfy the increasingly sophisticated customer needs (Baines et al., 2007).

- Process-related: The development of PSS solutions necessarily involves high interaction and sometimes blurred boundaries between the actors (Windahl and Lakemond, 2006). This creates a challenging situation for PSS organisations, which need to be in a permanent evolutionary process to create mutual value with their partners by adjusting their design and development activities, production capabilities and organisational structures. Hence, measuring effectiveness of development processes is significant in the context of PSS.

- Finance-related: PSS development adds service aspects into the product design space, which elevates the need to integrate an extended set of resources, competencies, activities and relationships related to product and service design processes from heterogeneous functions and external stakeholders (Isaksson et al., 2009). This cause companies to invest huge amount of money on collaborative activities, consultant services and knowledge management solutions.

- Service-related: Gaining knowledge from downstream processes, such as operations, maintenance, remanufacturing and feedback to development activities, could impact the designing and functionality behaviour of upcoming PSS offerings (Johnstone et al., 2008). Hence, experience sharing from operational activities to product development is considered to be critical in PSS practice, since companies are increasingly challenged to develop and offer value offerings to their customers in a continuous manner.

- Learning and growth-related: Since several lifecycle issues can affect the design decisions in a PSS context, PSS development requires the tight integration of many competences in knowing how to deliver seamless offerings to their customers (Isaksson et al., 2009). This new scenario emphasises the need to leverage the dynamic learning capabilities of the organisation, extending continuous learning beyond functional and organisational boundaries.

- Safety and sustainability-related: PSS development places higher customer expectations during service operations (Baines et al., 2007). Customers can expect quicker responses to their problems owing to their higher interdependent operations as well as higher safety and security regulations, e.g., passenger safety. Moreover, sustainability index allows measuring the generic concept of sustainability and turn the concept into action. It is an index that accounts for renewability and environmental load. There are numerous definitions and systems of operationalisation for sustainability (Robert et al., 2002). Ecological footprint analysis and lifecycle assessment are few to mention.

- Innovative capability, culture and environment-related: In a PSS context, companies need to come up with radical innovations to fulfil their customer needs (Isaksson et al., 2009). This calls the companies to have innovative culture, mind-set, innovative capabilities as well as inspiring innovative environments. 
Table 1 The multi-criteria performance measurement framework for PSS development with derived indicators from the study

\begin{tabular}{|c|c|c|c|}
\hline \multicolumn{2}{|c|}{$\begin{array}{l}\text { Hierarchical Level } 1 \\
\text { levels }\end{array}$} & Level 2 & Level 3 \\
\hline $\begin{array}{l}\text { Multi- } \\
\text { criteria PIs }\end{array}$ & $\begin{array}{l}\text { Corporate top } \\
\text { management }\end{array}$ & $\begin{array}{l}\text { Business function } \\
\text { management }\end{array}$ & $\begin{array}{l}\text { Functional and project } \\
\text { management }\end{array}$ \\
\hline \multirow[t]{5}{*}{$\begin{array}{l}\text { Customer } \\
\text { focus-related }\end{array}$} & $\begin{array}{l}\text { Overall company customer } \\
\text { satisfaction index }\end{array}$ & $\begin{array}{l}\text { Customer satisfaction } \\
\text { index per project }\end{array}$ & $\begin{array}{l}\text { Number of meetings with } \\
\text { customers }\end{array}$ \\
\hline & \multirow{4}{*}{$\begin{array}{l}\text { Customer retention index } \\
\text { Number of new revenue } \\
\text { sharing contracts }\end{array}$} & Customer collaboration & \multirow{3}{*}{$\begin{array}{l}\text { Number of product } \\
\text { improvement ideas } \\
\text { considered from } \\
\text { operational phase }\end{array}$} \\
\hline & & index per project & \\
\hline & & \multirow{2}{*}{$\begin{array}{l}\text { Number of projects } \\
\text { started from customer } \\
\text { input }\end{array}$} & \\
\hline & & & $\begin{array}{l}\text { Percentage of customer } \\
\text { needs fulfilled }\end{array}$ \\
\hline \multirow[t]{4}{*}{ Process-related } & $\begin{array}{l}\text { Average lead time per } \\
\text { project }\end{array}$ & $\begin{array}{l}\text { Project lead time/number } \\
\text { of projects }\end{array}$ & $\begin{array}{l}\text { Number of late design } \\
\text { modifications }\end{array}$ \\
\hline & \multirow[t]{3}{*}{$\begin{array}{l}\text { Design lifecycle time per } \\
\text { project }\end{array}$} & $\begin{array}{l}\text { Project design making } \\
\text { time }\end{array}$ & $\begin{array}{l}\text { Time spent at the process } \\
\text { stages and gates }\end{array}$ \\
\hline & & \multirow{2}{*}{$\begin{array}{l}\text { Redesign project lead } \\
\text { time/number of redesign } \\
\text { projects }\end{array}$} & $\begin{array}{l}\text { Time spent on project } \\
\text { 'stand-by' }\end{array}$ \\
\hline & & & Mean time to redesign \\
\hline \multirow[t]{5}{*}{ Finance-related } & \multirow{3}{*}{$\begin{array}{l}\text { ROI (on new technology } \\
\text { development, service } \\
\text { development, trainings, IT } \\
\text { investment in PD) }\end{array}$} & PM spent per project & PM spent \\
\hline & & Money spent per project & Cost for $\mathrm{X} /$ total cost \\
\hline & & \multirow{3}{*}{$\begin{array}{l}\text { Consultancy cost per } \\
\text { project }\end{array}$} & \multirow{3}{*}{$\begin{array}{l}\text { Note: Cost for } \mathrm{X}=\text { e.g., } \\
\text { cost for prototyping, } \\
\text { testing, simulation, } \\
\text { redesign service tools, etc }\end{array}$} \\
\hline & PD budget/total revenue & & \\
\hline & PD budget/consultancy cost & & \\
\hline \multirow[t]{6}{*}{ Service-related } & $\begin{array}{l}\text { Percentage of ROI from } \\
\text { servicing activity }\end{array}$ & \multirow{2}{*}{$\begin{array}{l}\text { Number of service } \\
\text { personal placed at } \\
\text { customers' sites }\end{array}$} & $\begin{array}{l}\text { Number of service aspects } \\
\text { used in ideas screening }\end{array}$ \\
\hline & Hours spent on product & & Number of lessons \\
\hline & servicing & \multirow{3}{*}{$\begin{array}{l}\text { PM spent on collaboration } \\
\text { with maintenance } \\
\text { department per project }\end{array}$} & learned considered from \\
\hline & Number of service & & operational phase \\
\hline & & & \multirow{2}{*}{$\begin{array}{l}\text { PM from the involvement } \\
\text { of maintenance and } \\
\text { operational personal }\end{array}$} \\
\hline & $\begin{array}{l}\text { Number of lessons learned } \\
\text { used in different projects }\end{array}$ & $\begin{array}{l}\text { Number of lessons } \\
\text { learned reused from } \\
\text { operational phases }\end{array}$ & \\
\hline \multirow[t]{7}{*}{$\begin{array}{l}\text { Learning and } \\
\text { growth-related }\end{array}$} & $\begin{array}{l}\text { Number of patents (applied } \\
\text { and granted) }\end{array}$ & \multirow{2}{*}{$\begin{array}{l}\text { Number of new } \\
\text { technology development } \\
\text { projects }\end{array}$} & \multirow{2}{*}{$\begin{array}{l}\text { Number of innovative } \\
\text { ideas selected for future } \\
\text { development }\end{array}$} \\
\hline & Number of PhDs & & \\
\hline & Number of specialists & $\begin{array}{l}\text { Number of PhDs per } \\
\text { function }\end{array}$ & Number of trainees \\
\hline & $\begin{array}{l}\text { Number of radical product } \\
\text { innovations }\end{array}$ & $\begin{array}{l}\text { Number of product and } \\
\text { process improvements }\end{array}$ & $\begin{array}{l}\text { Number of lessons } \\
\text { learned captured during } \\
\text { the stage-gates }\end{array}$ \\
\hline & & $\begin{array}{l}\text { Number of new acquired } \\
\text { skills per function }\end{array}$ & \multirow{3}{*}{$\begin{array}{l}\text { Number of training } \\
\text { material provided from } \\
\text { projects } \\
\text { Percentage of people } \\
\text { participation in trainings }\end{array}$} \\
\hline & & \multirow{2}{*}{$\begin{array}{l}\text { Number of trainees per } \\
\text { function }\end{array}$} & \\
\hline & & & \\
\hline
\end{tabular}


Table 1 The multi-criteria performance measurement framework for PSS development with derived indicators from the study (continued)

\begin{tabular}{|c|c|c|c|}
\hline \multicolumn{2}{|c|}{$\begin{array}{l}\text { Hierarchical Level } 1 \\
\text { levels }\end{array}$} & Level 2 & Level 3 \\
\hline $\begin{array}{l}\text { Multi- } \\
\text { criteria PIs }\end{array}$ & Corporate top management & $\begin{array}{l}\text { Business function } \\
\text { management }\end{array}$ & $\begin{array}{l}\text { Functional and project } \\
\text { management }\end{array}$ \\
\hline \multirow{5}{*}{$\begin{array}{l}\text { Safety and } \\
\text { sustainability- } \\
\text { related }\end{array}$} & Number of accidents & \multirow{2}{*}{$\begin{array}{l}\text { Number of failures due to } \\
\text { bad design per project }\end{array}$} & Number of design failures \\
\hline & Number of legal cases & & Number of product recalls \\
\hline & $\begin{array}{l}\text { Number of ISO } \\
\text { certifications }\end{array}$ & $\begin{array}{l}\text { Number of product recalls } \\
\text { per project }\end{array}$ & $\begin{array}{l}\text { Number of initiatives for } \\
\text { obtaining ISO certification }\end{array}$ \\
\hline & Sustainability index & $\begin{array}{l}\text { Number of methods and } \\
\text { tools used for } \\
\text { sustainability }\end{array}$ & $\begin{array}{l}\text { Number of methods/tools } \\
\text { used for sustainability }\end{array}$ \\
\hline & & $\begin{array}{l}\text { Percentage of initiatives } \\
\text { that lead to ISO } \\
\text { certification }\end{array}$ & \\
\hline \multirow{8}{*}{$\begin{array}{l}\text { Innovative } \\
\text { capability, } \\
\text { culture and } \\
\text { environment- } \\
\text { related }\end{array}$} & $\begin{array}{l}\text { Employment satisfaction } \\
\text { index }\end{array}$ & $\begin{array}{l}\text { Job satisfaction index per } \\
\text { function }\end{array}$ & $\begin{array}{l}\text { Level of autonomy and } \\
\text { empowerment in job }\end{array}$ \\
\hline & Job satisfaction index & Project satisfaction index & \multirow{3}{*}{$\begin{array}{l}\text { Number of employee } \\
\text { benefits (e.g., promotions, } \\
\text { rewards, supervision, } \\
\text { compensation, etc.) }\end{array}$} \\
\hline & Working climate index & Number of creative & \\
\hline & Number of implemented & & \\
\hline & $\begin{array}{l}\text { 1nnovative ideas/number of } \\
\text { proposed ideas }\end{array}$ & $\begin{array}{l}\text { Number of creative } \\
\text { environments per function }\end{array}$ & \multirow{2}{*}{$\begin{array}{l}\text { Number of social tools } \\
\text { available for informal } \\
\text { knowledge sharing }\end{array}$} \\
\hline & $\begin{array}{l}\text { Number of successful social } \\
\text { tools adoptions per project }\end{array}$ & $\begin{array}{l}\text { Number of supporting } \\
\text { tools for idea management }\end{array}$ & \\
\hline & \multirow{2}{*}{$\begin{array}{l}\text { Number of cross-functional } \\
\text { teams }\end{array}$} & \multirow{2}{*}{$\begin{array}{l}\text { Number of functions } \\
\text { represented in a cross- } \\
\text { functional team }\end{array}$} & $\begin{array}{l}\text { Number of new social ties } \\
\text { per project }\end{array}$ \\
\hline & & & $\begin{array}{l}\text { Number of prototypes } \\
\text { created }\end{array}$ \\
\hline
\end{tabular}

\section{Discussion and conclusions}

The paper has proposed a balanced, holistic and integrated performance measurement framework for PSS development projects to assess and analyse performances in a continuous manner. Using a BSC approach, the paper has explained how manufacturing companies can develop a performance measurement system, showing the guidelines for the selection of internal and external stakeholders, hierarchical levels, front- and back-end needs, criteria and performance indicators. As Kaplan and Norton (1996) argued, the full potential of the BSC will only be realised if an organisation links its measures clearly identifying the drivers of the performance. Hence, this study, based on the corporate vision and strategic objectives, has scaled down the criteria and the performance indicators in relation with three managerial hierarchical levels specific to PSS-oriented product development activities.

The framework has been developed considering the challenges for PSS providers. The three criteria added to the Kaplan and Norton definition of BSC (i.e., service, safety and sustainability, innovative capabilities culture and environment) aim at enabling the measuring of performances of service and intangible aspects that are typical of a PSS 
design context. In this way, the framework could make complex development processes more controllable by managers, extending the benefit of performance measurement in complex and articulated design processes. In this sense, measuring performances goes beyond merely reporting what has happened in the past, but can be seen as an instrument providing indirect indications and guidelines of what is working, and what is not, in the journey towards the transformation to a more service-intense manufacturing industry. In this way, the performance measurement framework can serve as a boundary object between different stakeholders, and as an instrument around which the transition to a PSS mind-set can be discussed.

Some challenges need to be taken into consideration when adopting a performance measurement framework in a PSS design context. First, the switch towards providing PSS is often the result of a radical change in the company strategy, involving new processes and new actors. Because of the novelty of the processes, the performance measured at beginning of such innovation might be not satisfactory if a long-term vision is not adopted. Any new process innovation requires some time to perform as desired, and the performance measurement framework helps as far as it is used as an instrument to identify the improvement needed. Instead if it is used only as an evaluator of the processes, the initial performance might be dissatisfying and thus guide to short-term decisions.

The framework proposed in the paper, as well as the indicators that populate it, is a proposal of application in a PSS context. The indicators have been influenced by the authors' involvement in the aerospace industry design processes. Those need to be customised based on the needs of each specific design process or design context, thus the framework can be considered as a guideline to drive the generation of more detailed and context-tailored performance measurement approaches. Attention should also be paid in the trade-off between the complexity of the PM approach and its benefit. The PM approach should be balanced in the light of the effort that needs to be spent to collect all the data needed to make it effective.

The proposed performance measurement framework is still at a conceptual level and would need to be further tested and validated in a real company setting. Future work shall focus on how to support the flow of information, both internally and externally, to support a reliable application of the performance management framework in a setting, such as early development stages, where information may be lacking or difficult to obtain. Adopting the framework will also require to set up a process granting the maintenance and the update of the performance management system to grant that the indicators fits with the evolving objectives of the company.

In conclusion, the paper aims to be a first step into the measurement of design process performances in a context of conjunct development of product and services. It proposes the extension of the traditional four dimensions of the BSC approach with three more criteria to better fit the PSS context. Indicators used are conceptual and defined accordingly to the authors' context of research; those should stimulate further discussion on deriving the performance indicators for PSS development that best fit different industrial context. The study welcomes researcher from different domains to test the framework by adopting specifically developed indicators. 


\section{Acknowledgements}

The authors thank project partners for providing the empirical base on which this paper is based.

\section{References}

Abran, A. and Buglione, L. (2003) 'A multidimensional performance model for consolidating balanced scorecards', Advances in Engineering Software, Vol. 34, pp.339-349.

Avison, D.E., Lau, F., Myers, M.D. and Nielsen, P.A. (1999) 'Action research', Communication of the ACM, Vol. 42, No. 1, pp.94-97.

Baines, T.S., Lightfood, H.W., Evans, S., Neely, A., Greenough, R., Peppard, J., Roy, R., Shehab, E., Braganza, A., Tiwari, A., Alcock, J.R., Angus, J.P., Bastl, M., Cousens, A., Irving, P., Johnson, M., Kingston, J., Lockett, H., Martinez, V., Michele, P., Tranfield, D., Walton, I.M. and Wilson, H. (2007) 'State-of-the-art in product-service systems', Journal of Engineering Manufacture, Vol. 221, No. 10, pp.1543-1552.

Bertoni, M., Eres, H. and Isaksson, O. (2011) 'Criteria for assessing the value of product-service system design alternatives: an aerospace investigation', Proceedings of the $3 \mathrm{rd}$ CIRP International Conference on Industrial Product Service Systems, 2-4 May, Braunschweig.

Bhagwat, R. and Sharma, M.K. (2007) 'Performance measurement of supply chain management: a balanced scorecard approach', Journal of Computers \& Industrial Engineering, Vol. 53, No. 1, pp.43-62.

Bourne, M., Keenerly, M. and Franco-Santos, M. (2005) 'Managing through measures: a study of impact on performance', Journal of Manufacturing Technology Management, Vol. 16, No. 4, pp.373-395.

Brax, S. (2005) 'A manufacturer becoming service provider - challenges and a paradox', Managing Service Quality, Vol. 15, No. 2, pp.142-155.

Chirumalla, K., Bertoni, A., Ericson, Å. and Isaksson, O. (2012) 'Knowledge-sharing network for product-service system development: Is it atypical?', in Shimomura, Y. and Kimita, K. (Eds.): Proceedings of the 4th CIRP International Conference on Industrial Product-Service Systems: The Philosopher's Stone for Sustainability, Springer-Verlag, Heidelberg, Germany, pp.109-114.

Collopy, P. and Hollingswort, P. (2009) 'Value driven design', Proceedings of the 9th AIAA Aviation Technology, Integration, and Operations Conference, 21-23 September, South Carolina.

Driva, H., Pawar, K.S. and Menon, U. (2000) 'Measuring product development performance in manufacturing organisations', International Journal of Production Economics, Vol. 63, No. 12, pp.147-159.

Figge, F., Hahn, T., Schaltegger, S. and Wagner, M. (2002) 'The sustainability balanced scorecard - linking sustainability management to business strategy', Business Strategy and the Environment, John Wiley \& Sons, No. 11, pp.269-284.

Fisher, D., Deshpande, S. and Livingston, J. (1998) Modeling the Lessons Learned Process (Research Report 123-11), The University of New Mexico, Albuquerque, NM.

Gaiardelli, P., Saccani, N. and Songini, L. (2007) 'Performance measurement of the after-sales service network-evidence from the automotive industry', Computers in Industry, Vol. 58, pp.698-708.

Harrison, A. (2006) 'Design for service - harmonizing product design with a services strategy', ASME Turbo Expo 2006: Power for Land, Sea and Air (GT2006), Barcelona, pp.135-143.

Isaksson, O., Larsson, T. and Ronnback, A.O. (2009) 'Development of product-service systems: challenges and opportunities for the manufacturing firm', Journal of Engineering Design, Vol. 20, No. 4, pp.329-348. 
Ittner, C.D. and Larcker, D.F. (1998) 'Are nonfinancial measures leading indicators of financial performance? An analysis of customer satisfaction', Journal of Accounting Research, Vol. 36, pp.1-35.

Johnstone, S., Dainty, A.R.J. and Wilkinson, A. (2008) 'Capturing the aftermarket in engineering organizations: opportunities and challenges', International Conference on Service Systems and Service Management, 30 June-2 July, Melbourne, Australia, pp.1-5.

Kaplan, R.S. and Norton, D.P. (1996) The Balanced Scorecard: Translating Strategy into Action, Harvard Business School Press, Boston.

Kaplan, R.S. and Norton, D.P. (2001) The Strategy-Focused Organization: How Balanced Scorecard Companies Thrive in the New Business Environment, Harvard Business School Press, Boston.

Keegan, D.P., Eiler, R.G. and Jones, C.R. (1989) 'Are your performance measures obsolete?', Management Accounting, Vol. 70, No. 12, pp.45-50.

Kennerly, M. and Neely, A. (2003) 'Measuring performances in a changing business environment', International Journal of Operation and Production Management, Vol. 23, No. 2, pp.213-229.

Lange, I.C. (2009) Performance Measurement of Industrial Services- Transparency on Service Processes and Results as the Basis for the Management of Product-Service Systems, $\mathrm{PhD}$ Thesis, Swiss Federal Institute of Technology, Zürich, No. 18757.

Larsson, A., Ericson, Å., Larsson, T. and Randall, D. (2008) 'Engineering 2.0: exploring lightweight technologies for the virtual enterprise', 8th International Conference on the Design of Cooperative Systems (COOP'08), 20-23 May, Carry-le-Rouet, France.

Lebas, M.J. (1995) 'Performance measurement and performance management', International Journal of Production Economics, Vol. 41, Nos. 1-3, pp.23-35.

Lingle, J.H. and Schiemann, W.A. (1996) 'From Balanced Scorecard to Strategy gauge: Is measurement worth it?', Management Review, March, pp.56-62.

Lynch, R.L. and Cross, K.F. (1991) Measure Up - The Essential Guide to Measuring Business Performance, Mandarin, London.

Miles, M.B. and Huberman, A.M. (1994) Qualitative Data Analysis: An Expanded Sourcebook, Sage Publications, California, USA.

Morelli, N. (2006) 'Developing new PSS, methodologies and operational tools', Journal of Cleaner Production, Vol. 14, No. 17, pp.1495-1501.

Neely, A. and Adams, C. (2001) 'The performance prism perspective', Journal of Cost Management, Vol. 15, No. 1, pp.7-15.

Neely, A.D. (1998) Measuring Business Performance: Why and How, Economist Books, London.

Nixon, B. (1999) 'Evaluating design performance', International Journal of Technology Management, Vol. 17, Nos. 7-8, pp.814-829.

Nudurupati, S.S., Bititci, U.S., Kumar, V. and Chan, F.T.S. (2011) 'State of the art literature review on performance measurement', Journal of Computers and Industrial Engineering, Vol. 60, No. 2, pp.279-290.

Oliva, R. and Kallenberg, R. (2003) 'Managing the transition from products to services', International Journal of Service Industry Management, Vol. 14, No. 2, pp.160-172.

Parida, A. (2006) Development of a Multi-Criteria Hierarchical Framework for Maintenance Performance Measurement: Concepts, Issues and Challenges, $\mathrm{PhD}$ Thesis, Luleå University of Technology, Luleå, p.37.

Parida, A., Åhren, T. and Kumar, U. (2003) 'Integrating maintenance performance with corporate balanced scorecard', Proceedings of 'COMADEM 2003', 27-29 August, Sweden, pp.53-59.

Pawar, K. and Driva, H. (1999) 'Performance measurement for product design and development in a manufacturing environment', International Journal of Production Economics, Vols. 60-61, pp.61-68. 
Prencipe, A. (2004) 'The changing boundaries of the firm: empirical evidence from the aircraft engine industry', in Cantwell, J., Gambardella, A. and Granstrand, O. (Eds.): The Economics and Management of Technological Diversification, Routledge, London, pp.265-296.

Robert, K-H., Schmidt-Bleek, B., de Larderel, J.A., Basile, G., Jansen, J.L., Kuehr, R., Thomas, P.P., Suzuki, M., Hawken, P. and Wackernagel, M. (2002) 'Strategic sustainable development - selection, design and synergies of applied tools', Journal of Cleaner Production, Vol. 10, No. 3, pp.197-214.

Sandström, J. and Toivanen, J. (2002) 'The problem of managing product development engineers: Can the balanced scorecard be an answer?', International Journal of Production Economics, Vol. 78, No. 1, pp.79-90.

Sveiby, K.E. (1997) The New Organizational Wealth: Managing and Measuring Knowledge-based Assets, Berrett-Koelher, San Francisco, CA.

Tomiyama, T. and Meijer, B.R. (2003) 'Service CAD', The SusProNet Launch Conference, 5-6 June, Amsterdam, pp.69-71.

van Halen, C., Vezzoli, C. and Wimmer, R. (2005) Methodology for Product Service System Innovation: How to DevelopClean, Clever and Competitive Strategies in Companies, Koninklijke Van Gorcum, Assen.

Waggoner, D., Neely, A. and Kennerley, M. (1999) 'The forces that shape organisational performance measurement systems: an interdisciplinary review', International Journal of Production Economics, Vols. 60-61, pp.53-60.

Wagner, L., Baureis, D. and Warschat, J. (2012) 'How to develop product-service systems in the fuzzy front end of innovation', International Journal of Technology Intelligence and Planning, Vol. 8, No. 4, pp.333-357.

Windahl, C. and Lakemond, N. (2006) 'Developing integrated solutions: the importance of relationships within the network', Industrial Marketing Management, Vol. 35, No. 7, pp.806-818.

Wisner, J.D., Leong, G.K. and Tan, K-C. (2005) Principles of Supply Chain Management: A Balanced Approach, South-Western College Publication, Mason, Ohio.

Woodruff, R.B. (1997) 'Customer value: the next source for competitive advantage', Journal of the Academy of Marketing Science, Vol. 25, No. 2, pp.139-153.

Yang, J-H. (2009) 'A balanced performance measurement scorecard approach for product service systems', Proceedings of International Conference on Business Intelligence and Financial Engineering, 24-26 July, Beijing, China, pp.548-551.

Yin, R.K. (2009) Case Study Research: Design and Methods, 4th ed., Sage Publications, Thousand Oaks, CA. 